\title{
OPTIMASI PEMBACAAN SUHU KAMERA TERMAL MENGGUNAKAN REGRESI LINIER
}

\section{Thermal Camera Temperature Readings Optimization Using Linear Regression}

\author{
Sevia Indah Purnama ${ }^{1 *}$, Irmayatul Hikmah ${ }^{2}$, Mas Aly Afandi ${ }^{3}$, Elsa Sri Mulyani ${ }^{4}$ \\ 1,2 Prodi Teknik Biomedis Fakultas Teknik Telekomunikasi dan Elektro Institut Teknologi Telkom Purwokerto \\ ${ }^{3,4}$ Prodi Teknik Telekomunikasi Fakultas Teknik Telekomunikasi dan Elektro Institut Teknologi Telkom Purwokerto \\ Jl. D.I. Panjaitan 128 , Purwokerto, 53147, Jawa Tengah, Indonesia
}

Corresponding author e-mail: $1 *$ sevia@ittelkom-pwt.ac.id

\begin{abstract}
Abstrak
Salah satu gejala seseorang terkena penyakit Covid-19 adalah demam. Pengecekan suhu tubuh sebelum memasuki area yang padat seperti sekolah, kantor, toko, dan rumah sakit menjadi protokol wajib yang harus dilakukan. Salah satu alat yang dapat digunakan untuk mengecek suhu tubuh adalah kamera termal. Kamera termal memiliki kekurangan yaitu kesalahan pembacaan suhu yang tinggi. Hal ini disebabkan kamera termal yang digunakan memiliki resolusi yang rendah. Penelitian ini bertujuan untuk menurunkan nilai kesalahan pembacaan suhu pada kamera termal dengan metode regresi linier. Hasil dari penelitian ini menunjukkan metode regresi linier mampu menurunkan tingkat kesalahan pembacaan suhu sebesar 5,27\% pada pembacaan suhu $36^{\circ} \mathrm{C}$. Penurunan kesalahan pembacaan juga terjadi sebesar $5,27 \%$ pada suhu $37^{\circ} \mathrm{C}$ dan $6,44 \%$ pada suhu $38^{\circ} \mathrm{C}$. Berdasarkan hasil yang didapatkan, penelitian ini menunjukan bahwa regresi linier dapat diterapkan pada kamera termal dan memberikan penurunan tingkat kesalahan pembacaan suhu pada kamera termal.
\end{abstract}

Kata Kunci : kamera termal, suhu, regresi linier

\begin{abstract}
Fever is one of the symptoms of a person with Covid-19. Body temperature must be checked e before entering crowded areas such as schools, offices, shops, and hospitals. It is a mandatory protocol that must be done. One of the tools that can be used to check body temperature is a thermal camera. Thermal cameras have the disadvantage of a high temperature reading error. This is because the thermal camera used has a low resolution. This study aims to reduce the value of the temperature reading error on the thermal camera using the linear regression method. The linear regression method is able to reduce the error rate of temperature readings by $5.27 \%$ at $36^{\circ} \mathrm{C}$ reading. The reduction in reading error also occurred by $5.27 \%$ at $37{ }^{\circ} \mathrm{C}$ and $6.44 \%$ at $38^{\circ} \mathrm{C}$. Based on the results obtained, this study shows that linear regression can be applied to thermal cameras and provides a decrease in the error rate of temperature readings on thermal cameras.
\end{abstract}

Keywords: thermal camera, temperature, linier regression

Article info:

Submitted: $09^{\text {th }}$ January 2021

Accepted: $16^{\text {th }}$ February 2021

How to cite this article:

S. I. Purnama, I. Hikmah, M. A. Afandi, E. S. Mulyani, "OPTIMASI PEMBACAAN SUHU KAMERA TERMAL MENGGUNAKAN REGRESI LINIER”, BAREKENG: J. Il. Mat. \& Ter., vol. 15, no. 1, pp. 127-136, Mar. 2021.

\section{(†) (2)}

This work is licensed under a Creative Commons Attribution-ShareAlike 4.0 International License.

Copyright (C) 2021 Sevia Indah Purnama, Irmayatul Hikmah, Mas Aly Afandi, Elsa Sri Mulyani 


\section{PENDAHULUAN}

Covid-19 adalah penyakit baru yang telah menjadi pandemi. Penyakit ini harus diwaspadai karena penularan yang relatif cepat, memiliki tingkat mortalitas yang tidak dapat diabaikan, dan belum adanya terapi definitif [1]. Penularan ini terjadi umumnya melalui droplet dan kontak dengan virus kemudian virus dapat masuk ke dalam mukosa yang terbuka [2]. Penularan dapat diminimalisir dengan cara memakai masker, mencuci tangan dan menjaga jarak serta menerapkan perilaku hidup bersih dan sehat [3]. Dalam masa pandemi ini, banyak kantor, institusi dan pusat perbelanjaan yang menerapkan pengencekan protokol kesehatan kepada pegawai dan pengunjungnya. Pengunjung diharuskan memakai masker dan mencuci tangan sebelum masuk ke pusat perbelanjaan, kemudian penjaga akan mengukur suhu tubuh pengunjung, jika suhunya di atas $36,9^{\circ} \mathrm{C}$, pengunjung tersebut tidak boleh masuk. Permasalahan akan terjadi ketika ada banyak orang yang harus dicek suhu tubuhnya sehingga menimbulkan antrian cek suhu tubuh. Antrian ini akan memakan waktu lama jika pengecekan suhu tubuh dilakukan secara manual menggunakan thermogun. Bahkan di beberapa tempat, antrean panjang dapat menimbulkan kerumunan. Kerumunan memiliki potensi menjadi klaster Covid-19 yang baru. Hal tersebut dapat dicegah dengan menggunakan peralatan pengukuran suhu tubuh yang lebih baik.

Infrared pertama kali ditemukan sekitar tahun 1800 [4]. Seiring berjalannya waktu, infrared ini berkembang menjadi infrared array pada awal 1970 [5]. Thermal kamera merupakan sensor pasif yang menangkap radiasi infrared yang dipancarkan oleh benda hitam. Panjang gelombang infrared yang dipancarkan oleh manusia sebesar $10 \mu \mathrm{m}$ bisa ditangkap oleh thermal kamera ini [6]. Keuntungan menggunakan kamera thermal adalah ketika cahaya sekitar meredup, kamera thermal ini mampu untuk mendeteksi kehadiran objek dibanding kamera optik yang bergantung pada pencahayaan, sebab yang ditangkap oleh kamera thermal adalah radiasi panas [7]. Penelitian tentang kamera thermal untuk mengukur suhu tubuh manusia telah dilakukan [8] [9] [10]. Pada tahun 2010 ketika wabah SARS menyebar, Nguyen dkk membuat penelitian untuk membandingkan pengukuran dari tiga tipe kamera thermal dengan hasil tipe Opto-therm dan FLIR memiliki akurasi yang baik. Pengukuran suhu tubuh menggunakan kamera termal dapat menjadi solusi untuk menjaga jarak pada masa pandemi ini [11].

Jumlah sensor yang digunakan pada kamera thermal akan mempengaruhi resolusinya [12]. Range pengukuran pada AMG8833 berada di antara $0^{\circ} \mathrm{C}$ hingga $80^{\circ} \mathrm{C}$ dengan akurasi $\pm 2.5^{\circ} \mathrm{C}$. Alat ini mampu mendeteksi objek pada jarak hingga $7 \mathrm{~m}$. Resolusi yang dimiliki sebesar 8 x8 atau 64 piksel dan mampu bekerja dengan baik pada frame range maksimum $10 \mathrm{~Hz}$ atau $10 \mathrm{fps}$. Sudut pembacaan sebesar $60^{\circ}$ [13]. Thermal kamera mampu menggambarkan panas yang tersebar pada suatu benda [14]. Dengan menggunakan program matlab, kita mampu meniru data panas pada objek dengan menampilkan bentuk citra atau citra kuantitatif dalam bentuk warna batang. Benda yang memiliki suhu rendah dengan benda yang memiliki suhu tinggi akan memiliki warna batang yang berbeda [15]. Kepresisian dapat ditingkatkan dengan merata-rata data suhu dari semua poin pendeteksian [16] [17]. Penelitian kamera thermal untuk mengukur gejala demam pernah dilakukan dengan mengukur akurasi yang disesuaikan dengan standar deviasi ketika kalibrasi sebesar $2,3^{\circ} \mathrm{C}[18]$.

Tingkat kesalahan pembacaan suhu pada kamera thermal perlu diminimalisir guna menentukan data suhu yang akurat. Penelitian ini menggunakan kamera termal AMG 8833 dengan resolusi 8x8 piksel yang memiliki akurasi rendah dalam mengukur suhu tubuh sebab toleransi akurasi yang dimiliki terlalu besar [6]. Penelitian ini mengajukan metode regresi linier untuk menurunkan toleransi pembacaan dari kamera termal AMG 8833 menjadi lebih baik dan dapat digunakan untuk mengukur suhu tubuh manusia dengan tepat.

\section{METODE PENELITIAN}

\subsection{Kamera Thermal}

Penelitian ini dimulai dengan mengumpulkan semua bahan dan alat yang digunakan. Peralatan yang digunakan adalah AMG8833 sebagai kamera termal resolusi rendah, Arduino Uno dengan mikrokontroler AT Mega 328 dan LCD Display. Data masuk melalui AMG8833 kemudian diproses ke mikrokontroler. Hasil pemrosesan data ini kemudian ditampilkan ke LCD. Gambaran besar sistem ditunjukkan pada Gambar 1. 


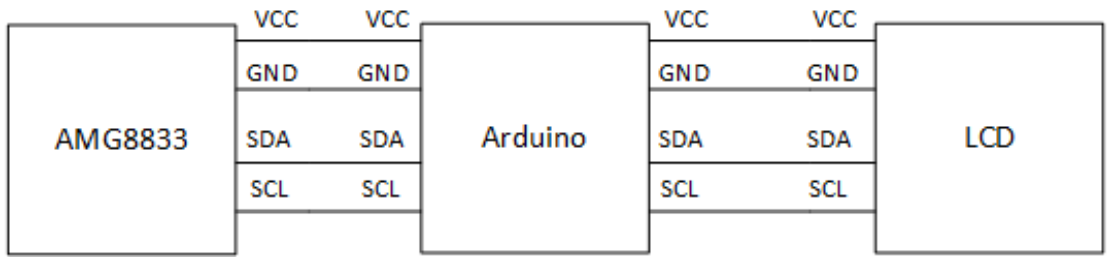

Gambar 1. Blok diagram sistem yang digunakan

Gambar 1 menunjukkan garis besar sistem yang digunakan pada penelitian ini. Kamera termal merupakan sensor yang digunakan dan bertindak sebagai input sistem. Mikrokontroler merupakan piranti pengolah data yang digunakan untuk memprosess data. LCD display merupakan perangkat untuk melihat hasil data pengolahan dan bertindak sebagai output sistem. Kamera termal yang digunakan adalah AMG8833 berfungsi untuk membaca suhu objek yang diukur. Kamera ini memberi pembacaan dengan resolusi 8x8 piksel. Tiap piksel dari kamera ini merepresentasikan suhu yang dibaca berdasarkan prinsip kerja pembacaan suhu infra merah. Piksel pada kamera ini mewakili suhu untuk tiap-tiap titik pembacaan. Total informasi suhu yang didapatkan menggunakan kamera ini adalah 64 titik didapatkan dari 8x8 informasi suhu untuk tiap-tiap piksel. Data hasil pembacaan suhu di tiap-tiap piksel dikirim ke mikrokontroler untuk pengolahan lebih lanjut. Pengiriman data suhu dari kamera thermal ke mikrokontroler memanfaatkan komunikasi serial I2C. Komunikasi I2C pada mikrokontroler memanfaatkan 2 jalur komunikasi yaitu SDA dan SCL.

Tabel 1. Konfigurasi pin antara AMG8833 dan Mikrokontroler

\begin{tabular}{cc}
\hline Pin AMG8833 & Pin AT Mega 328 \\
\hline VCC & $3,3 \mathrm{~V}$ \\
\hline GND & GND \\
\hline SDA & PC4 \\
\hline SCL & PC5 \\
\hline
\end{tabular}

Tabel 1 menunjukkan hubungan pin antara AMG8833 dengan mikrokontroler AT Mega 328. Tabel 1 memberikan informasi bahwa catu daya yang dibutuhkan oleh kamera thermal AMG 8833 adalah 3,3V. PC4 pada mikrokontoller merupakan pin SDA dan PC5 pada mikrokontroler adalah pin SCL. Komunikasi AMG8833 menggunakan 12C sehingga semua array data suhu yang berjumlah 64 dikirim ke AT Mega 328 melalui pin SDA dan SCL dalam sekali pengiriman. Mikrokontroler akan membaca data dan mencari suhu tertinggi di antara 64 piksel tersebut. Setelah suhu tertinggi ditemukan, mikrokontroler mencari posisi suhu tersebut sesuai diagram kartesian $\mathrm{X}$ dan $\mathrm{Y}$.

$$
\text { err }=\left|\frac{A V-T V}{A V}\right| x 100 \%
$$

Persamaan (1) digunakan untuk menghitung nilai galat pada pembacaan suhu yang didapatkan oleh AMG8833. err merupakan nilai galat, $A V$ merepresentasikan actual value yaitu nilai aktual pada objek yang di ukur menggunakan thermometer sebagai alat pembanding, $T V$ menunjukkan test value yaitu nilai pembacaan suhu menggunakan kamera thermal AMG8833 ketika membaca objek yang sama dengan termometer. Nilai galat akan dihitung sebanyak $2 \mathrm{x}$ yaitu saat pengambilan sebelum optimasi pembacaan menggunakan regresi linier dan setelah optimasi menggunakan regresi liniar. Hal tersebut dilakukan untuk mengukur penurunan galat yang didapatkan setelah prosess optimasi menggunakan metode regresi linier.

\subsection{Regresi Linear}

Regresi linier merupakan sebuah metode untuk menemukan garis yang mewakilkan 2 variabel yang saling berhubungan agar memiliki kesesuain terbaik. Regresi linear digunakan karena data-data menunjukan bahwa termometer dan kamera AMG 8833 memiliki karakteristik linear. Semakin tinggi suhu yang dibaca menggunakan termometer, maka AMG 8833 juga membaca suhu yang lebih tinggi pula. Perbedaan hasil pembacaan dari termometer dan kamera thermal AMG 8833 dinyatakan dalam satuan galat. Penelitian ini berfokus untuk memperkecil galat yang dihasilkan oleh kamera thermal AMG 8833 terhadapt termometer dalam skala ${ }^{\circ} \mathrm{C}$. 


$$
y=a x+c
$$

Persamaan (2) merupakan persamaan garis linearitas dimana y adalah respon garis. Respon garis merupakan data yang ingin didekati nilainya yaitu data hasil pembacaan suhu menggunakan termometer. Variabel $x$ adalah penaksir yang merupakan data hasil pembacaan menggunakan AMG 8833. Variable a adalah kemiringan atau koefisien dari garis regresi. Variabel c adalah konstanta yang menyatakn jarak dari titik perpotongan antara y dan x. Persamaan (1) dari garis regresi menyaratkan nilai a dan c yang terbaik.

$$
\begin{gathered}
a=\frac{n \sum x y-\left(\sum x\right)\left(\sum y\right)}{n \sum x^{2}-\left(\sum x\right)^{2}} \\
c=\frac{\left(\sum y\right)\left(\sum x^{2}\right)-\left(\sum x\right)\left(\sum x y\right)}{n \sum x^{2}-\left(\sum x\right)^{2}}
\end{gathered}
$$

Persamaan (3) dan (4) adalah persamaan untuk menghitung nilai konstanta dan kemiringan dengan berbagai nilai pada $\mathrm{x}$ dan y. Penelitian ini menggunakan beberapa variabel suhu yaitu $36^{\circ} \mathrm{C}, 37^{\circ} \mathrm{C}$, dan $38^{\circ} \mathrm{C}$. Persamaan tersebut membentuk nilai pembacaan dari kamera termal AMG 8833 yang baru sehingga output dari kamera thermal AMG 8833 tidak ditampilkan pada LCD dengan data yang mentah melainkan data yang telah di olah menggunakan persamaan (2). Hasil dari pengolahan ini kemudian di ukur nilai galatnya menggunakan persamaan (1) untuk mengetahui apakah optimasi menggunakan persamaan (2) menurunkan nilai galat atau tidak pada kamera termal AMG 8833.

\section{HASIL DAN PEMBAHASAN}

Penelitian ini menggunakan 3 varian data pembacaan suhu yaitu suhu objek berupa air panas bersuhu $36^{\circ} \mathrm{C}, 37^{\circ} \mathrm{C}$, dan $38^{\circ} \mathrm{C}$. Masing-masing variasi data suhu tersebut dilakukan pengambilan data sebanyak 10 data pembacaan suhu menggunakan kamera termal dengan jangka waktu pengambilan tiap 1 menit sekali. Data-data tersebut didapatkan sebelum pengolahan menggunakan regresi linear untuk mengetahui kondisi awal sebelum pengolahan. Dengan membandingkan data sebelum pengolahan menggunakan regresi liner dan setelah menggunakan metode regresi linier diharapkan dapat dijadikan dasar untuk mengukur tingkat penurunan nilai galat pada kamera termal saat mengukur suhu.

Tabel 2. Data Suhu $36^{\circ} \mathrm{C}$ Sebelum Pengolahan

\begin{tabular}{cccc}
\hline No. & $\begin{array}{c}\text { Suhu Termometer } \\
\left({ }^{\circ} \mathbf{C}\right)\end{array}$ & $\begin{array}{c}\text { Suhu Kamera } \\
\text { Termal }\left({ }^{\circ} \mathbf{C}\right)\end{array}$ & Galat $(\%)$ \\
\hline $\mathbf{1}$ & 36,00 & 33,75 & 6,25 \\
\hline $\mathbf{2}$ & 36,00 & 33,75 & 6,25 \\
\hline $\mathbf{3}$ & 36,00 & 34,00 & 5,56 \\
\hline $\mathbf{4}$ & 36,00 & 34,25 & 4,86 \\
\hline $\mathbf{5}$ & 36,00 & 34,00 & 5,56 \\
\hline $\mathbf{6}$ & 36,00 & 34,00 & 5,56 \\
\hline $\mathbf{7}$ & 36,00 & 34,00 & 5,56 \\
\hline $\mathbf{8}$ & 36,00 & 34,00 & 5,56 \\
\hline $\mathbf{9}$ & 36,00 & 34,00 & 5,56 \\
\hline $\mathbf{1 0}$ & 36,00 & 34,00 & 5,56 \\
\hline
\end{tabular}

Tabel 3. Data Suhu $37^{\circ} \mathrm{C}$ Sebelum Pengolahan

\begin{tabular}{cccc}
\hline No. & $\begin{array}{c}\text { Suhu Termometer } \\
\left({ }^{\circ} \mathbf{C}\right)\end{array}$ & $\begin{array}{c}\text { Suhu Kamera } \\
\text { Termal }\left({ }^{\circ} \mathbf{C}\right)\end{array}$ & Galat $(\%)$ \\
\hline $\mathbf{1}$ & 37,00 & 34,75 & 6,08 \\
\hline $\mathbf{2}$ & 37,00 & 35,00 & 5,41 \\
\hline $\mathbf{3}$ & 37,00 & 34,75 & 6,08 \\
\hline $\mathbf{4}$ & 37,00 & 34,75 & 6,08 \\
\hline $\mathbf{5}$ & 37,00 & 34,75 & 6,08 \\
\hline $\mathbf{6}$ & 37,00 & 34,75 & 6,08 \\
\hline $\mathbf{7}$ & 37,00 & 34,50 & 6,76 \\
\hline $\mathbf{8}$ & 37,00 & 34,50 & 6,76 \\
\hline $\mathbf{9}$ & 37,00 & 34,50 & 6,76 \\
\hline $\mathbf{1 0}$ & 37,00 & 34,50 & 6,76 \\
\hline
\end{tabular}


Tabel 4. Data Suhu $38^{\circ} \mathrm{C}$ Sebelum Pengolahan

\begin{tabular}{cccc}
\hline No. & $\begin{array}{c}\text { Suhu Termometer } \\
\left({ }^{\circ} \mathbf{C}\right)\end{array}$ & $\begin{array}{c}\text { Suhu Kamera } \\
\text { Termal }\left({ }^{\circ} \mathbf{C}\right)\end{array}$ & Galat $(\mathbf{\%})$ \\
\hline $\mathbf{1}$ & 38,00 & 35,25 & 7,23 \\
\hline $\mathbf{2}$ & 38,00 & 35,50 & 6,58 \\
\hline $\mathbf{3}$ & 38,00 & 35,50 & 6,58 \\
\hline $\mathbf{4}$ & 38,00 & 35,25 & 7,24 \\
\hline $\mathbf{5}$ & 38,00 & 35,25 & 7,24 \\
\hline $\mathbf{6}$ & 38,00 & 35,25 & 7,24 \\
\hline $\mathbf{7}$ & 38,00 & 35,75 & 5,92 \\
\hline $\mathbf{8}$ & 38,00 & 35,25 & 7,24 \\
\hline $\mathbf{9}$ & 38,00 & 35,25 & 7,24 \\
\hline $\mathbf{1 0}$ & 38,00 & 35,25 & 7,24 \\
\hline
\end{tabular}

Berdasarkan pengambilan data sebelum pengolahan yang ditampilkan pada Tabel 2, Tabel 3, dan Tabel 4 dapat diketahui bahwa pembacaan suhu menggunakan kamera termal memiliki perbedaan terhadap suhu aktualnya. Nilai galat sebelum menggunakan regresi linier berkisar antara 4,86\%-7,24\%. Nilai galat tersebut cukup tinggi apabila digunakan untuk mengukur suhu tubuh. Nilai galat 4,86\% - 7,24\% memberikan perbedaan $1,75^{\circ} \mathrm{C}-2,75^{\circ} \mathrm{C}$. Nilai tersebut sesuai dengan batas toleransi kamera thermal AMG8833. Namun nilai galat tersebut akan berdampak signifikan untuk membaca suhu tubuh di masa pandemi Covid-19.

Tabel 5. Komponen Regresi Linear

\begin{tabular}{cccccc}
\hline No & $\mathbf{y}$ & $\mathbf{x}$ & $\mathbf{x}^{\mathbf{2}}$ & $\mathbf{y}^{\mathbf{2}}$ & $\mathbf{x y}$ \\
\hline $\mathbf{1}$ & 36,00 & 33,98 & 1154,64 & 1296 & 1223,28 \\
\hline $\mathbf{2}$ & 37,00 & 34,68 & 1202,70 & 1369 & 1283,16 \\
\hline $\mathbf{3}$ & 38,00 & 35,35 & 1249,62 & 1444 & 1343,30 \\
\hline
\end{tabular}

Data pada Tabel 5 merupakan pengolahan awal yang didapatkan berdasarkan data sebelumnya pada Tabel 2, Tabel 3, dan Tabel 4. Nilai y pada Tabel 5 merupakan nilai rata-rata pengukuran suhu aktual menggunakan termometer selama prosess pengukuran. Nilai x pada Tabel 5 adalah nilai rata-rata dari pengukuran suhu menggunakan kamera termal selama prosess pengukuran. Berdasarkan data pada Tabel 5 didapatkan nilai $\sum x$ adalah $104,01 \sum y$ adalah $111 \sum x^{2}$ adalah 3606,97 $\sum y^{2}$ adalah $4109 \sum x y$ adalah 3849,74. Komponen-komponen pada Tabel 5 dapat digunakan untuk menghitung nilai a dan $\mathrm{c}$ pada Persamaan (2) untuk mendapatkan permodelan metode regresi liner. Persamaan (3) dan Persamaan (4) digunakan untuk menghitung nilai a dan nilai c sehingga didapatkan nilai a adalah 1,46 dan nilai c adalah 13,61. Nilai a dan c yang dihitung kemudian disubstitusi pada Persamaan (2) sehingga didapatkan sebuah permodelan $y=1,46 x-13,61$. Permodelan tersebut digunakan untuk optimasi pembacaan suhu kamera termal dan mendapatkan hasil yang lebih baik.

Tabel 6. Data Suhu $36^{\circ} \mathrm{C}$ Setelah Pengolahan Regresi Linear

\begin{tabular}{cccc}
\hline No. & $\begin{array}{c}\text { Suhu Termometer } \\
\left({ }^{\circ} \mathbf{C}\right)\end{array}$ & $\begin{array}{c}\text { Suhu Kamera } \\
\text { Termal }\left({ }^{\circ} \mathbf{C}\right)\end{array}$ & Galat $(\%)$ \\
\hline $\mathbf{1}$ & 36,00 & 35,67 & 0,92 \\
\hline $\mathbf{2}$ & 36,00 & 35,67 & 0,92 \\
\hline $\mathbf{3}$ & 36,00 & 36,03 & 0,08 \\
\hline $\mathbf{4}$ & 36,00 & 36,4 & 1,11 \\
\hline $\mathbf{5}$ & 36,00 & 36,03 & 0,08 \\
\hline $\mathbf{6}$ & 36,00 & 36,03 & 0,08 \\
\hline $\mathbf{7}$ & 36,00 & 36,03 & 0,08 \\
\hline $\mathbf{8}$ & 36,00 & 36,03 & 0,08 \\
\hline $\mathbf{9}$ & 36,00 & 36,03 & 0,08 \\
\hline $\mathbf{1 0}$ & 36,00 & 36,03 & 0,08 \\
\hline
\end{tabular}

Data pada Tabel 6 yang sudah mengalami proses regresi linear kemudian dibandingkan dengan data pada Tabel 2 yang belum mengalami proses regresi linear. Perbandingan yang sama-sama dilakukan pada suhu $36^{\circ} \mathrm{C}$ menunjukkan bahwa optimasi untuk menurunkan galat memiliki dampak yang cukup signifikan. Rata-rata galat yang dihasilkan pada Tabel 2 adalah 5,63\% sedangkan rata-rata galat pada Tabel 6 adalah $0,35 \%$. Berdasarkan hasil tersebut regresi linier memiliki dampak untuk menurunkan nilai galat pada kamera 
termal untuk membaca suhu objek $36^{\circ} \mathrm{C}$. Grafik perbedaan hasil pengukuran suhu pada suhu $36^{\circ} \mathrm{C}$ ditunjukkan pada Gambar 2.

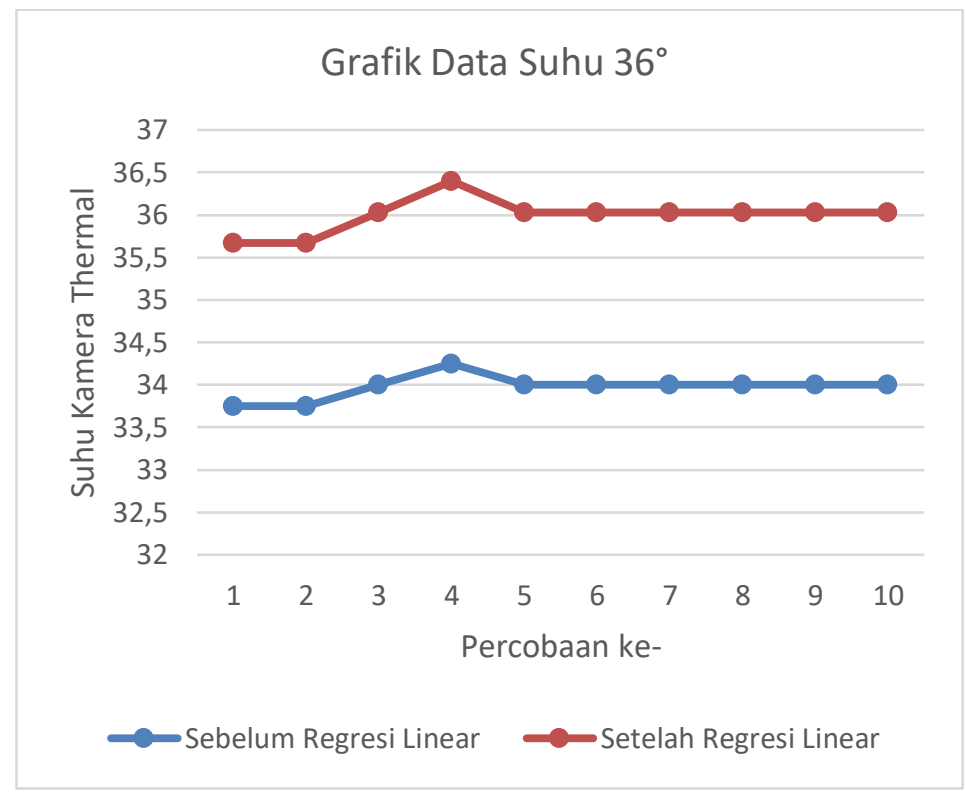

Gambar 2. Grafik perbandingan pembacaan suhu sebelum dan setelah proses regresi linear pada suhu $36^{\circ} \mathrm{C}$

Gambar 2 menunjukkan perbedaan perbandingan pembacaan suhu sebelum diproses dengan regresi linear dan setelah diproses dengan regresi linear. Garis yang berwarna biru menunjukkan pembacaan suhu $36^{\circ} \mathrm{C}$ yang dibaca $34^{\circ} \mathrm{C}$ sebelum menerapkan regresi linear, sedangkan Garis yang berwarna merah menunjukkan pembacaan mendekati suhu $36^{\circ} \mathrm{C}$ setelah menerapkan regresi linear.

Tabel 7. Data Suhu $37^{\circ} \mathrm{C}$ Setelah Pengolahan Regresi linier

\begin{tabular}{cccc}
\hline No. & $\begin{array}{c}\text { Suhu Termometer } \\
\left({ }^{\circ} \mathbf{C}\right)\end{array}$ & $\begin{array}{c}\text { Suhu Kamera } \\
\text { Termal }\left({ }^{\circ} \mathbf{C}\right)\end{array}$ & Galat $(\%)$ \\
\hline $\mathbf{1}$ & 37,00 & 37,13 & 0,35 \\
\hline $\mathbf{2}$ & 37,00 & 37,49 & 1,32 \\
\hline $\mathbf{3}$ & 37,00 & 37,13 & 0,35 \\
\hline $\mathbf{4}$ & 37,00 & 37,13 & 0,35 \\
\hline $\mathbf{5}$ & 37,00 & 37,13 & 0,35 \\
\hline $\mathbf{6}$ & 37,00 & 37,13 & 0,35 \\
\hline $\mathbf{7}$ & 37,00 & 36,76 & 0,65 \\
\hline $\mathbf{8}$ & 37,00 & 36,76 & 0,65 \\
\hline $\mathbf{9}$ & 37,00 & 36,76 & 0,65 \\
\hline $\mathbf{1 0}$ & 37,00 & 36,76 & 0,65 \\
\hline
\end{tabular}

Data pada Tabel 7 yang sudah mengalami proses regresi linear kemudian dibandingkan dengan data pada Tabel 3 yang belum mengalami proses regresi linear. Perbandingan yang sama-sama dilakukan pada suhu $37^{\circ} \mathrm{C}$, terlihat bahwa optimasi untuk menurunkan galat memiliki dampak yang cukup signifikan. Ratarata galat yang dihasilkan pada Tabel 3 adalah 6,28\% sedangkan rata-rata galat pada Tabel 7 adalah 0,58\%. Berdasarkan hasil tersebut regresi linier memiliki dampak untuk menurunkan nilai galat pada kamera termal untuk membaca suhu objek $37^{\circ} \mathrm{C}$. Grafik perbedaan hasil pengukuran suhu pada suhu $37^{\circ} \mathrm{C}$ ditunjukkan pada Gambar 3. 


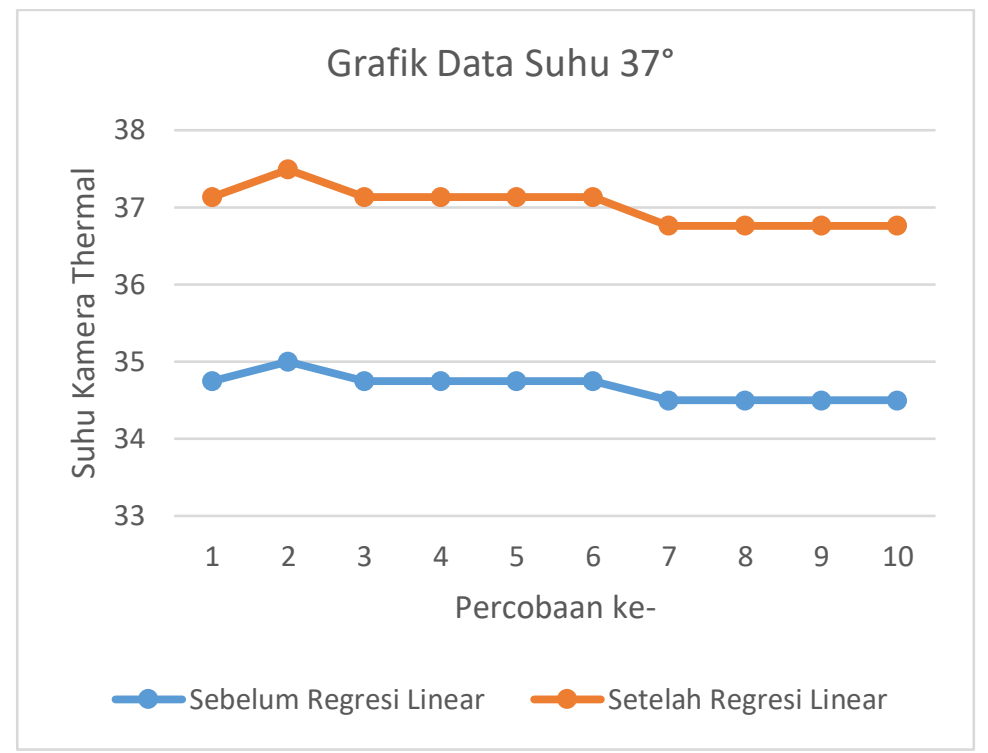

Gambar 3. Grafik perbandingan pembacaan suhu sebelum dan setelah proses regresi linear pada suhu $37^{\circ} \mathrm{C}$

Gambar 3 menunjukkan perbedaan perbandingan pembacaan suhu sebelum diproses dengan regresi linear dan setelah diproses dengan regresi linear. Garis yang berwarna biru menunjukkan pembacaan suhu $37^{\circ} \mathrm{C}$ yang dibaca $34^{\circ} \mathrm{C}$ sampai $35^{\circ} \mathrm{C}$ sebelum menerapkan regresi linear, sedangkan Garis yang berwarna merah menunjukkan pembacaan mendekati suhu $37^{\circ} \mathrm{C}$ setelah menerapkan regresi linear.

Tabel 8. Data Suhu $38^{\circ} \mathrm{C}$ Setelah Pengolahan Regresi Linier

\begin{tabular}{cccc}
\hline No. & $\begin{array}{c}\text { Suhu } \\
\text { Termometer }\left({ }^{\circ} \mathbf{C}\right)\end{array}$ & $\begin{array}{c}\text { Suhu Kamera } \\
\text { Termal }\left({ }^{\circ} \mathbf{C}\right)\end{array}$ & Galat $(\%)$ \\
\hline $\mathbf{1}$ & 38,00 & 37,86 & 0,37 \\
\hline $\mathbf{2}$ & 38,00 & 38,22 & 0,58 \\
\hline $\mathbf{3}$ & 38,00 & 38,22 & 0,58 \\
\hline $\mathbf{4}$ & 38,00 & 37,86 & 0,37 \\
\hline $\mathbf{5}$ & 38,00 & 37,86 & 0,37 \\
\hline $\mathbf{6}$ & 38,00 & 37,86 & 0,37 \\
\hline $\mathbf{7}$ & 38,00 & 38,59 & 1,55 \\
\hline $\mathbf{8}$ & 38,00 & 37,86 & 0,37 \\
\hline $\mathbf{9}$ & 38,00 & 37,86 & 0,37 \\
\hline $\mathbf{1 0}$ & 38,00 & 37,86 & 0,37 \\
\hline
\end{tabular}

Data pada Tabel 8 yang sudah mengalami proses regresi linear kemudian dibandingkan dengan data pada Tabel 4 yang belum mengalami proses regresi linear. Perbandingan yang sama-sama dilakukan pada suhu $38^{\circ} \mathrm{C}$, terlihat bahwa optimasi untuk menurunkan galat memiliki dampak yang cukup signifikan. Ratarata galat yang dihasilkan pada Tabel 4 adalah 6,97\% sedangkan rata-rata galat pada Tabel 8 adalah $0,52 \%$. Berdasarkan hasil tersebut regresi linier memiliki dampak untuk menurunkan nilai galat pada kamera termal untuk membaca suhu objek $38^{\circ} \mathrm{C}$. Dari keseluruhan percobaan yang dilakukan terhadap berbagai variable suhu yaitu $36^{\circ} \mathrm{C}, 37^{\circ} \mathrm{C}$ dan $38^{\circ} \mathrm{C}$ didapatkan hasil bahwa regresi linier mampu menurunkan galat untuk pembacaan pada kamera termal. Grafik perbedaan hasil pengukuran suhu pada suhu $38^{\circ} \mathrm{C}$ ditunjukkan pada Gambar 4. 


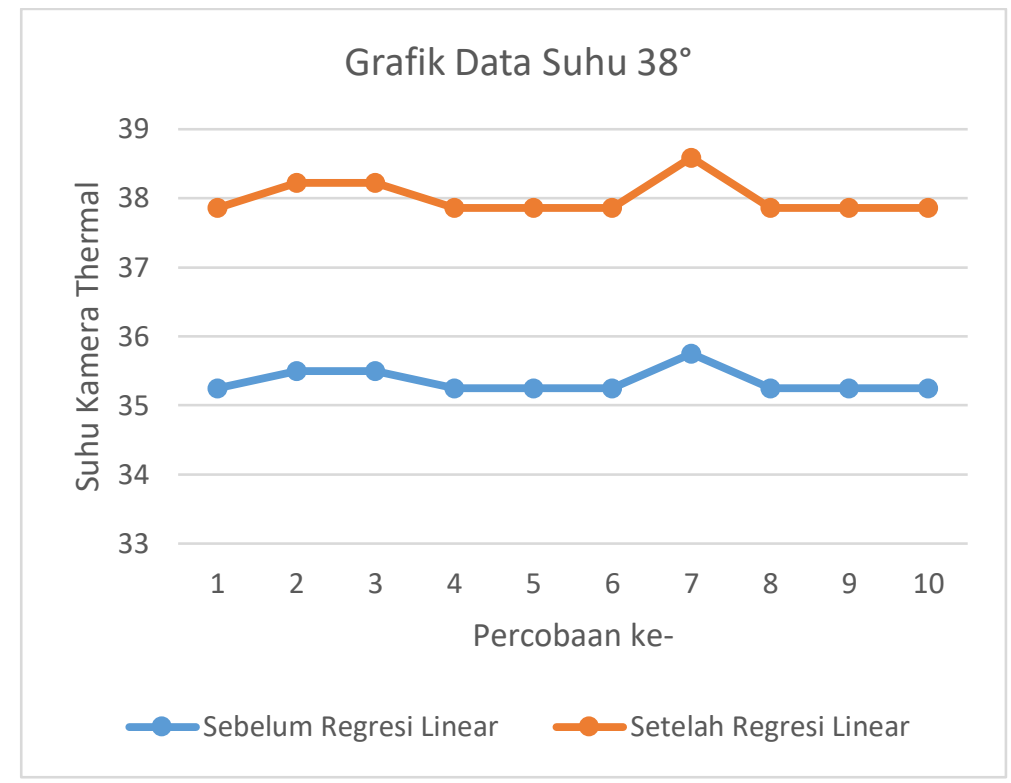

\section{Gambar 4. Grafik perbandingan pembacaan suhu sebelum dan setelah proses regresi linear pada suhu $38^{\circ} \mathrm{C}$}

Gambar 4 menunjukkan perbedaan perbandingan pembacaan suhu sebelum diproses dengan regresi linear dan setelah diproses dengan regresi linear. Garis yang berwarna biru menunjukkan pembacaan suhu $38^{\circ} \mathrm{C}$ yang dibaca $35^{\circ} \mathrm{C}$ sebelum menerapkan regresi linear, sedangkan Garis yang berwarna merah menunjukkan pembacaan mendekati suhu $38^{\circ} \mathrm{C}$ setelah menerapkan regresi linear.

\section{KESIMPULAN}

Berdasarkan hasil data pada percobaan yang telah dilakukan, didapatkan sebuah kesimpulan bahwa regresi liner dapat dimanfaatkan untuk menurunkan galat pembacaan suhu pada kamera termal. Optimasi menggunakan metode regresi linier memiliki dampak yang signifikan. Pada suhu $36^{\circ} \mathrm{C}$ terjadi penurunan galat sebesar $5,27 \%$. Pada suhu $37^{\circ} \mathrm{C}$ terjadi penurunan galat sebesar $5,72 \%$. Pada suhu $38^{\circ} \mathrm{C}$ terjadi penurunan galat sebesar $6,44 \%$. Berdasarkan hasil tersebut dapat disimpulkan bahwa regresi liner perlu digunakan sebagai optimasi pembacaan suhu pada kamera termal sehingga hasil membacaan suhu menjadi lebih akurat.

\section{UCAPAN TERIMA KASIH}

Ucapan terima kasih disampaikan kepada Lembaga Penelitian dan Pengabdian Kepada Masyarakat (LPPM) Institut Teknologi Telkom Purwokerto yang telah mendanai penelitian serta jajaran pimpinan Fakultas Teknik Telekomunikasi dan Elektro yang telah mendukung penelitian dengan support peralatan labolatorium.

\section{DAFTAR PUSTAKA}

[1] A. Susilo, C. M. Rumende, C. W. Pitoyo, W. D. Santoso, M. Yulianti, Herikurniawan, R. Sinto, G. Singh, L. Nainggolan, E. . J. Nelwan, L. K. Chen, A. Widhani, E. Wijaya, B. Wicaksana, M. Maksum, F. Annisa, C. O. Jasirwan and E. Yunihastuti, "Coronavirus Disease 2019: Tinjauan Literatur Terkini," Jurnal Penyakit Dalam Indonesia, vol. 7, no. 1, pp. 45-67, 2020.

[2] D. Handayani, D. R. Hadi, F. Isbaniah, E. Burhan and H. Agustin, "Penyakit Virus Corona 2019," Jurnal Respirologi Indonesia, vol. 40, no. 2, pp. 119-129, April 2020.

[3] K. K. R. Indonesia, Keputusan Menteri Kesehatan Republik Indonesia Nomor HK.01.07/MENKES/382/2020 Tentang Protokol Kesehatan Bagi Masyarakat di Tempat dan Fasilitas Umum dalam Rangka Pencegahan dan Pengendalian Corona Virus Disease 2019 (Covid-19), Jakarta: Kementrian Kesehatan Republik Indonesia, 2020.

[4] R. Grade and T. B. Moeslund, "Thermal Cameras and Applications a Survey," Machine Vision and Applications, vol. 25, p. 245-262, 2014. 
[5] H. Kaplan, Practical Applications of Infrared Thermal Sensing and Imaging Equipment 3rd ed, Bellingham, Washington: The Society of Photo-Optical Instrumentation Engineers, 2007.

[6] Supria and M. Nasir, "Monitoring of Body Temperature Non Contact Using Amg8833 Thermal Camera and Face Detection," in Seminar Nasional Terapan Riset Inovatif (SENTRINOV), 2020.

[7] M. A. Muda, R. Alandani and G. M. Arya, "Thermal Vision pada Manusia dengan Pengaruh Terhadap Warna Pakaian," 5th Indonesian Symposium on Robotic Systems and Control, pp. 243-248, 6 Juli 2017.

[8] K. Nishi, M. Demura, J. Miura and S. Oishi, "Use of Thermal Point Cloud for Thermal Comfort Measurement and Human Pose Estimation in Robotic Monitoring," EEE International Conference on Computer Vision Workshops (ICCVW), pp. 14161423, 22-29 October 2017.

[9] T. F. Tan, S. S. Teoh, J. E. Fow and K. S. Yen, "Embedded human detection system based on thermal and infrared sensors for anti-poaching application," IEEE Conference on Systems, Process and Control (ICSPC), pp. 37-42, 2016.

[10] M. Teutsch, T. Muller, M. Huber2 and J. Beyerer, "Low Resolution Person Detection with a Moving Thermal Infrared Camera by Hot Spot Classification," IEEE Conference on Computer Vision and Pattern Recognition Workshops, pp. 209216, 2014.

[11] A. V. Nguyen, N. J. Cohen, H. Lipman, C. M. Brown, N.-A. Molinari, W. L. Jackson, H. Kirking, P. Szymanowski, T. W. Wilson, B. A. Salhi, R. R. Roberts, D. W. Stryker and D. B. Fishbein, "Comparison of 3 Infrared Thermal Detection Systems and Self-Report for Mass Fever Screening," Emerging Infectious Diseases, vol. 6, no. 11, pp. 1710-1717, 2010.

[12] E. Benli, Y. Motai and J. Rogers, "Human Behavior-Based Target Tracking With an Omni-Directional Thermal Camera," IEEE Transactions on Cognitive and Developmental Systems, vol. 11, no. 1, pp. 36-50, 2019.

[13] G. Cerutti, R. Prasad and E. Farella, "Convolutional Neural Network on Embedded Platform for People Presence Detection in Low Resolution Thermal Images," ICASSP , pp. 7610-7614, 2019.

[14] P.-J. Lee, T.-A. Bui and C.-C. Lo, "Temperature Model and Human Detection in Thermal Image," IEEE 7th Global Conference on Consumer Electronics (GCCE), pp. 57-59, 2018.

[15] G. Batchuluun, Y. W. Lee, D. T. Nguyen, T. D. Pham and K. R. Park, "Thermal Image Reconstruction Using Deep Learning," IEEE Access, vol. 8, pp. 126839-126858, 2020.

[16] R. Ali, P. Yunfeng, A. Ali, H. Ali, N. Akhter, J. Ahmed and A. Jalil, "Passive Autofocusing System for a Thermal Camera," IEEE Access,, vol. 8, pp. 130014-130022, 2020.

[17] N. A. Ivanescu and L. Ciupitu, "Vision system for human body infrared thermography,," 19th International Workshop on Robotics in Alpe-Adria-Danube Region (RAAD 2010), pp. 353-356, 2010.

[18] E. Yusuf, H. Syamsudin, M. Mohammed, S. AL-Zubaidi and S. A.K., "2019 Novel Coronavirus Disease (Covid-19): Thermal Imaging System for Covid-19 Symptom Detection Using IOT Technology," Revista Argentina de Clínica Psicológica, vol. 29, no. N5, pp. 234-239, 2020. 
